\title{
Türkiye'de Uzun Bisiklet Parkurlarının Bisiklet Kullanımına Etkisinin İncelenmesi
}

\author{
Seda Cabiroğlu ${ }^{1 *}$, Abdulkadir Özden ${ }^{2}$ \\ 1* Sakarya Uygulamalı Bilimler Üniversitesi, Lisansüstü Eğitim Enstitüsü, Sakarya, Türkiye, (ORCID: 0000-0003-1714-5137), sedacabiroglu00@gmail.com \\ ${ }^{2}$ Sakarya Uygulamalı Bilimler Üniversitesi, Teknoloji Fakültesi, İnşaat Mühendisliği Bölümü, Sakarya, Türkiye, (ORCID: 0000-0002-3657-890X), \\ aozden@subu.edu.tr
}

(International Conference on Design, Research and Development (RDCONF) 2021 - 15-18 December 2021)

(DOI: 10.31590/ejosat.1042311)

ATIF/REFERENCE: Cabiroglu, S. \& Özden, A. (2021). Türkiye'de Uzun Bisiklet Parkurlarının Bisiklet Kullanımına Etkisinin Incelenmesi. Avrupa Bilim ve Teknoloji Dergisi, (32), 850-857.

\section{$\ddot{O} \mathbf{z}$}

Kentsel hareketliliğin arttı̆̆ı, daha yoğun ve kompleks bir yaşam tarzı edindiğgimiz son yıllarda artan trafik problemlerine çözüm üretme mecburiyeti ortaya çıkmıştır. Sürdürülebilir ulaşım kapsamında değerlendirilen ve son yıllarda hızla popülaritesi artan mikro hareketlilik kavramı, bisiklet ve skuter gibi bireysel ulaşım araçlarını ve yaya ulaşımını kapsamaktadır. Ayrıca, hala etkisinde olduğumuz Covid-19 pandemisi ile bireysel hareketliliğin sağlı etkisi öne çıkmakta, ilgili kurumlarında da bu konuda geçici ve kalıcı altyapı hizmetleri sunduğu görülmektedir. Bu çalışma, ülkemizde aktif bisiklet kullanıcılarının, Türkiye'deki uzun bisiklet parkurlarına karşı bakış açılarını değerlendirmek ve kullanıcıların mevcut durum değerlendirmesini, beklentilerini, talep ve şikayetlerini araştırmak amacı ile yapılmıştır. Elde edilen sonuçlarda, sürüş güvenliği, sürüş kolaylığı, fiziksel altyapı kalitesi ve motorlu taşıtlarla olan etkileşimi az olan parkurların insanlar tarafından tercih sebebi olduğu vurgulanmıştır. Aynı zamanda, bisiklete sahip olmayan insanların büyük çoğunluğunun bisiklet altyapısının yeterli olduğu güvenli parkurlarda bisiklet kullanma fikrine olumlu yaklaştığı görülmüştür. Bisiklet yolları ile ilgili bilgilerin dinamik olarak kullanıcılarla paylaşılması konusunda kurumların etkin bir politika izlemediği ifade edilmiştir.

Anahtar Kelimeler: Bisikletli Ulaşım, Sürdürülebilir Ulaşım, Bisiklet Yolları, Sürüş Güvenliği, Mikromobilite.

\section{Effect of Long Cycling Tracks on Cycling Behaviour in Turkey}

\begin{abstract}
In recent years, we have adopted a more intense and complex lifestyle along with the increasing urban mobility and it has become necessary to find solutions to increasing traffic problems. The concept of micromobility, which is considered within the scope of sustainable transportation, has gained popularity in recent years and includes individual transportation vehicles such as bicycles and scooters, and pedestrian transportation. Furthermore, with the Covid-19 pandemic, the health impact of individual mobility comes to the fore, and it is seen that the relevant institutions provide temporary and permanent infrastructure services in this regard. This study was carried out with the aim of evaluating the perspectives of active cyclists in Turkey towards long cycling tracks and investigating the current situation, expectations, demands and complaints of users. In the results obtained, it was emphasized that the safety, ease of driving, quality of physical infrastructure and the tracks with less interaction with motor vehicles are preferred by people. At the same time, it has been observed that the majority of people who do not have bicycles or do not cycle regularly have a positive intention to the idea of cycling on safe tracks where physical infrastructure is sufficient. It has been stated that institutions do not follow an effective policy regarding sharing information about bicycle paths and tracks, and their cycling condition with users.
\end{abstract}

Keywords: Cycling, Sustainable Transportation, Bicycle Tracks, Cycling Safety, Micromobility.

\footnotetext{
*Bu çalışma birinci yazarın ikinci yazar danışmanlığında yürütülen yüksek lisans tezinden üretilmiştir.

${ }^{* *}$ Sorumlu Yazar: sedacabiroglu00@gmail.com
} 


\section{Giriş}

Son yıllarda artan kentsel nüfüs, araç sahipliğindeki artışlar ve insanların hareketlilik ihtiyacı ulaşıma olan talebi ve ulaşım planlamasının önemini artırmıştır. Şehir hayatının gelişmesi ile beraber insanlar ekonomik ve sosyal faaliyetlerin içerisinde daha çok yer almaya başlamış, günlük yolculuk sayıları da beraberinde artış göstermiştir. Motorlu taşıt kullanımının fazla olması ve trafik sıkışıklığındaki artışlar, karbon salınımını da zararlı düzeylere çıkarmıştır (Barth \& Boriboonsomsin, 2008). Yaşanan bu durum insanların sağlığına olumsuz etki ettiği gibi, aynı zamanda ekonomik ve sosyal açıdan negatif tesirler ortaya çıkarmaktadır. $\mathrm{Bu}$ nedenlerden dolayı, son yıllarda çevre bilinci yüksek toplumların sürdürülebilir ulaşıma olan eğilimi artmıştır. Ayrıca, sürdürülebilir ulaşım felsefesinin de sıkça konuşulmaya başlaması ile mevcut trafik karmaşasından daha etkin çözümlere yönelme mecburiyeti ortaya çıkmıştır (Schiller \& Kenworthy, 2017).

Farklı tanımlar ve anlamlandırmalar olsa da genel itibari ile sürdürülebilir ulaşım; çevreye zarar vermeyen, ekonomik ve sosyal yönlerden tutarlı ve gelecek nesillerin ulaşım ihtiyacını riske atmayan ulaşım sistemi olarak adlandırılabilir (Litman \& Burwell, 2006). İnsanların toplu taşıma araçlarını kullanması, yaya ulaşımı, bisiklet ve skuter tercih etmeleri, AUS ile etkin planlama ve işletme politikaları ve akaryakıt sistemlerindeki değişimler sürdürülebilir ulaşım kavramını desteklemektedir. Özellikle, mikro hareketlilik kavramı çerçevesinde bisiklet, skuter vb. kısa ve orta mesafe, çevre dostu ve bireysel ulaşım araçları ve öncü olarak görülen bisikletli ulaşım son yıllarda gittikçe artan bir ilgi görmektedir.

Kent içi ulaşımda kullanılan bisiklet; günlük ulaşım ihtiyacının karşılanması, zararlı çevresel etkileri azaltmak, sağlıklı yaşam ve spor, turizm ve hobi amaçlı olarak da kullanılabilmektedir (Vith \& Mössner, 2017). Dünya genelinde turizm sektöründe son trendler arasında insanların turizm için bisiklet kullandıkları ve bisiklet turizmine teşvik edildikleri görülmektedir (Lumsdon, 2000). Çoğalan talebi karşılamak üzere yeni rotalar ve bisiklet ağları geliştirilmeye başlanmış, altyapı ve bisiklete olan yatırım dünya genelinde artmıştır. Örneğin; Avrupa'da neredeyse tüm Avrupa kıtasını birbirine bağlayan uzun bisiklet yolları çalışmaları yapılmaktadır. "EuroVelo" adı verilen bu girişim, Avrupa'nın tüm ülkelerinde belirli standartları olan, kaliteli ve uzun bisiklet yollarının uygulamasını, potansiyel bisiklet kullanıcılarını bu anlamda bilgilendirmeyi ve günlük gezintiler, bisiklet turizmi, sağlıklı ve sürdürülebilir bir seyahat için insanları teşvik etmeyi hedeflemektedir (Weston, 2012). Eurovelo Projesi kapsamında geliştirilen rotalardan; Akdeniz Rotası (EV8), ülkemizde İzmir kentinden geçmektedir.

Ülkemizde ise, uzun bisiklet parkurları ile ilgili yeterli altyapı olmadığı gibi bu konudaki bilimsel araştırmalar da sınırlıdır. Konya, Sakarya ve Eskişehir gibi bisikletli ulaşım konusunda uzun yıllarıdır yatırım yapan şehirler bu konuda öncülük etmekte olsa da genel olarak hem toplum bilinci oluşturma hem de etkin ve verimli altyapı sağlama konularında ciddi eksiklikler bulunmaktadir.

Cengiz ve Kahvecioğlu (2016), Çanakkale kent merkezinde yaptıkları çalışmada bağlantısallık (connectivity) ve bütünlük (completeness) çerçevesinde tasarlanan üç uzun parkur bisiklet yolunun değerlendirmesini mevcut fiziksel altyapı koşulları, trafik yoğunluğu, rekreasyon alanlarının varlığı ve kullanıcı yoğunluğuna bağlı kısım kısım değerlendirmiş, toplamda 75 puan üzerinden en fazla puana sahip kesimin sadece 23 puan aldığ görülmüştür. Bu da halihazırda kullanılan bisiklet yollarının ciddi eksiklikleri olduğunu göstermektedir.

Öztürk ve Çoruh (2019) yaptıkları çalışmada Gümüşhane ili için bisiklet kullanımının değerlendirmesini anket yöntemi ile uygulamış ve gerekli altyapının olması durumunda bisikletli ulaşımın daha çok tercih edileceği sonucuna ulaşılmıştır. Katılımcıların cinsiyet bazlı değerlendirmesinde genel bisiklet kullanmama gerekçesi, güvenlik etkisi ve hava şartları bakımından kadınlar ve erkekler arasında anlamlı bir fark bulunmamıştır. Benzer bir çalışmada bisiklet paylaşım sistemini Kocaeli ili için değerlendiren araştırmacılar, başta yol altyapısı ve sürüş güvenliği olmak üzere, konfor ve çevre düzenlemeleri bakımında geliştirilebilir sonucuna ulaşmıştır (Altuntaş vd., 2020).

Bireylerin bisiklet kullanımı ve kullanım potansiyeli hakkında yapılan bir diğer çalışmada, ulaşım ücretlerinin artması söz konusu olursa bisiklete yönelim tercihleri sorulmuş ve yaklaşık \%63 oranında olumlu cevap alınmıştır. Ancak asıl önemli husus, bisiklet kullanımını tercih etmeyecek bireylerin bu düşüncelerinde $\% 53$ ile altyapı eksikliği ve yolların bozukluğu ve $\% 55$ ile de trafik güvenliğindeki problemlerin yatmasıdır (Barut \& Yücetürk, 2017).

Bir diğer taraftan, insanlık tarihi boyunca zaman zaman kendini gösteren ancak 2019 itibari ile hayatımızda kalıcı değişikliklere sebep olan Covid-19 pandemisi, toplu taşımaya olan talebi azaltmış, bireysel ulaşımın önemini ve etkinliğini gözler önüne sermiştir. Yapılan bilimsel çalışmalarda bisiklet ve skuter gibi mikro hareketlilik türlerinin bütün dünyada ciddi rağbet gördüğü ve yönetimlerin geçici ve kalıcı altyap1 hizmetlerine yöneldiği görülmüştür (Barbieri vd. 2021; Özden \& Şahin, 2020; Zhang vd. 2021).

Uzun bisiklet parkurları ile ilgili yapılan çalışmalarda mevcut bisiklet yollarında sürüş güvenliği, altyapı kalitesi (Chen \& Chen, 2013), toplu taşıma ile entegrasyonları (Saplığlu \& Aydın, 2018), diğer erişim noktaları ile bağlantıları ve yol boyu tesisleri (Chen \& Chen, 2013; Winters vd., 2010) etkin parametreler olarak karşımıza çıkmaktadır.

Winters vd., (2011) yaptıkları kapsamlı çalışmada bisiklet kullanıcılarını motive eden etkenlerin başında trafik gürültüsü ve kirlilikten uzak olması, mevcut trafik yolundan ayrılmış olması ve seyir keyfi veren güzergahlar olması gelmektedir. Ayrıca, sürüş güvenliği, sürüş kolaylığı, fiziksel altyapı kalitesi ve motorlu taşıtlarla olan etkileşimi az olan parkurların tercih sebebi olduğu vurgulanmıştır.

$\mathrm{Bu}$ çalışma, ülkemizde aktif bisiklet kullanan insanların, Türkiye'deki uzun bisiklet parkurlarına karşı bakış açılarını değerlendirmek ve bisiklet kullanıcılarının mevcut durum değerlendirmesini, beklentilerini, talep ve şikayetlerini araştırmak amacı ile yapılmıştır. Aktif bisiklet kullananların güvenli bisiklet ulaşımı hakkındaki düşünceleri, yaşadıkları sıkıntılar, bisiklet yollarının projelendirme özellikleriyle ilgili olumlu ve olumsuz düşünceleri kapsam içerisine alınarak değerlendirmeler yapılmış ve öneriler sunulmuştur. Kent içi ulaşım ve kısa mesafe bisiklet kullanıcılarının mevcut problemleri kapsam dışı bırakılmış olsa da halihazırda uzun parkur dışındaki bisiklet kullanıcılarının da hangi şartlarda bu parkurlarda bisiklet kullanabilecekleri değerlendirilmiştir. 


\section{Materyal ve Metot}

Türkiye'deki aktif bisiklet kullanıcılarının uzun bisiklet parkurlarına bakış açılarının değerlendirilmesi ve bisiklet kullanıcılarının beklenti, talep ve şikayetlerinin araştırılması için gerekli olan veriler anket yöntemi kullanılarak elde edilmiştir.

Uzun Parkur Bisiklet Yolu değerlendirme çalışması için katılımcilara sorulacak sorular Google Anket platformundan yararlanılarak hazırlanmıştır. Anket dışsal geçerliliğinin sağlanması için ulaştırma alanında uzman iki akademisyenden görüş alınmış ve değerlendirmeler 1şığında anket soruları tasarlanmıştır. İçsel geçerliliğin sağlanması için ise bazı sorular anket içinde farklı şekillerde tekrarlanmıştır.

Anket, katılımcıların verdiği cevaplara göre değişen kategoriler içermekle birlikte toplamda dokuz bölümden ve maksimum 24 sorudan oluşmaktadır. Demografik bilgilerin alındığ 1 soruların ardından bisiklet sahipliğine ve kullanımına göre katılımcılara farklı düzey sorular yönlendirilmiştir. Bisiklet kullanmayan katılımcıların kullanmama gerekçeleri değerlendirilmeye çalışılmış, bisiklet kullanıcılarının ise uzun parkur kullanımları hakkındaki görüşleri likert tipi ölçek ile alınmıştır.

Son bölümde ise üç adet açık uçlu soru katılımcıların isteğine bırakılarak sunulmuştur. Bu sorular ile katılımcıların uzun bisiklet parkurlarıyla ilgili fikirlerini açıkça ifade edebilecekleri bir platform sunularak önceki bölümlerde kapsam dışı konuların da değerlendirilmesi sağlanmıştır. Hazırlanan anket sosyal medya platformları üzerinden başta bisiklet sosyal grupları olmak üzere farklı platformlarda paylaşılmıştır. Mayıs ve Haziran aylarında katılımcılara açık olan anket, geçerlilik ve ön değerlendirme sonucunda 443 katılımeı ile sonlandırılmıştır. Anket sonuçlarının değerlendirilmesinde frekans, yüzdelikler ve betimleyici istatistik yöntemleri kullanılmıştır.

\section{Araştırma Sonuçları ve Tartışma}

Araştırma sonuçları katılımcıların demografik verileri, bisiklet kullanımları ve uzun parkur sürücülerinin değerlendirmeleri kategorilerinde değerlendirilmiştir. Demografik verilerde cinsiyet, yaş, medeni durum, eğitim durumu, hanedeki kişi sayısı, aylık gelir, hanedeki araç sayısı soruları yönlendirilmiştir. Sonrasında katılımcılara 'bisikletiniz var mı?" sorusu sorulmuş evet cevabı verenler bisiklet kullanımı bölümüne, hayır cevabı verenler ise bisiklet kullanım potansiyeli bölümüne yönlendirilmiştir. $\mathrm{Bu}$ şekilde iki farklı cevabı veren katılımcı için farklı değerlendirmeler yapılmıştır.

Bisikleti olmayan kat1lımcılara öncelikle 'bisiklet kullanmayı biliyor musunuz?" sorusu sorulmuş daha sonra da bisiklet kullanımına ve uzun bisiklet parkurlarına bakış açıları likert ölçeğinde sorular sorularak katılımcıların yanıtları değerlendirilmiștir. Bisiklete sahip katılımcılara ise bisiklet kullanım amaçları, uzun parkurlarda bisiklet kullanımına karşı bakış açıları sorulmuş, bisiklet kullanımının çevresel etkileri, konaklama ve tesislerin varlığı, yol yapım kalitesi ve güvenilirlik kapsamlı soruları içeren likert ölçeği kullanılarak uzun parkurlarla ilgili bisiklet kullanıcılarının fikirleri değerlendirilmiştir.

Son bölümde ise üç adet isteğe bağlı soru yönlendirilmiş ve özellikle uzun parkur bisiklet kullanıcılarının sürüş tercihleri, problemleri ve ilgili kurumların bisiklet altyapısı ve bu konudaki perspektifleri hakkında açık beyanda bulunabilecekleri bir platform oluşturulmuştur.

\subsection{Demografik Veriler}

Katılımcılarım demografik verileri incelendiğinde erkeklerin ağırlıkta olduğu görülmektedir. 443 geçerli anketin \%62'si (276) erkek ve \%38’i (167) kadın olarak gözlemlenmiştir. Yaş gruplarına göre yapılan değerlendirmede katılımcıların \%27'sinin 25 yaş ve altı, $\% 42$ 'sinin $26-40$ yaş aralı̆̆ında, $\% 28$ 'inin 41-59 yaş aralığında, \%3'ünün 60 yaş ve üzerinde olduğu görülmüştür (Şekil 1-a ve b). 60 yaş üzeri katılımcıların sayısının azlığı, bu yaş grubundakilerin bisiklet kullanım potansiyelinin düşük olmasına ve dijital okur yazarlık problemine bağlanmaktadır. Eğitim durumuna ilişkin yöneltilen soruda katılımcılarının \%4'ünün ilköğretim, \%14 lise, \%61 önlisans-lisans ve \%20 lisansüstü olarak dağıllım göstermiştir.

Ulaşım alanında yapılan çalışmalarda en önemli demografik soruların başında hane kişi sayısı ve araç sahipliği soruları gelmektedir. Bu kapsamda yöneltilen sorularda, katılımcılarının $\% 30$ 'u 2 kişi ve altı, \%52'si 3-4 kişi ve \%18'i ise 5 ve üzeri olarak dağılım göstermiştir (Şekil 1-d). Araç sahipliği ile ilgili yöneltilen soruda ise katılımcıların \%15'inin 2 ve üzeri araca sahip olduğu, \%54'ünün 1 araç sahibi olduğu, \%31'inin ise araç sahip olmadığı gözlemlenmiştir. Anket katılımcılarının gelir düzeyleri ile ilgili soruya verilen cevaplar değerlendirildiğinde ise katılımcıların \%11'i 7.501-10.000 TL, \%13'ü 10.001 TL ve üzeri, \%21'i 5.0017.500 TL, \%23'ü 3.501-5.000 TL, \%32'si 3.500 TL ve altı gelire sahip kişilerden oluşmaktadır (Şekil 1-c).
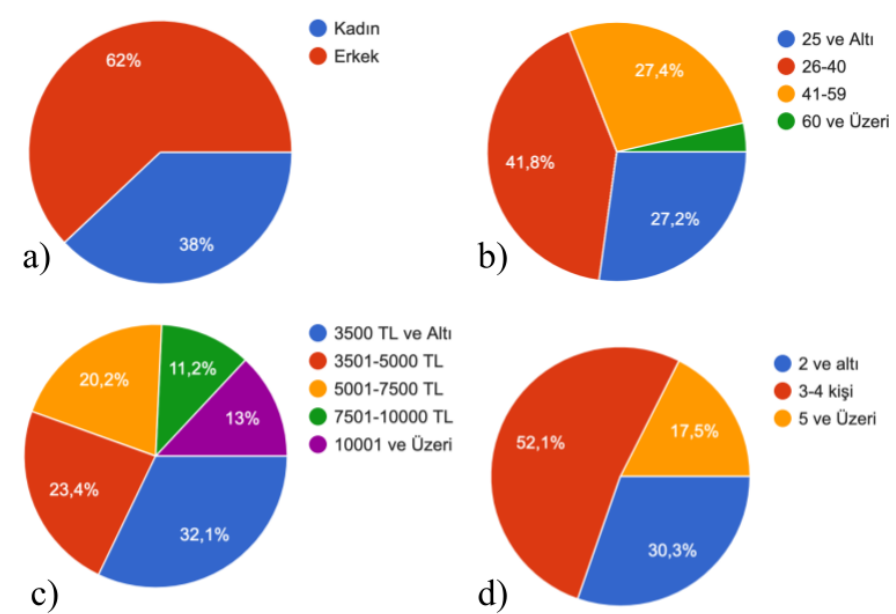

2 ve altı 3-4 kişi 5 ve Üzeri

Şekil 1. Demografik Veriler

\subsection{Genel Bisiklet Kullanım Potansiyeli:}

Katılımcıların genel bisiklet kullanım durumları, sıklığı ve sürüs mesafeleri ile ilgili yapılan değerlendirmede katılımcıların $\% 25$ 'i haftada 1-2 gün, $\% 32$ 'si haftada 3-4 gün, $\% 20$ 'si ise her gün bisiklet kullandığını belirtmiştir. Yolculuk mesafesi incelendiğinde ise katılımcıların dengeli dağıldı $\breve{g}_{1}$ gözlenmektedir. Anket katılımcılarının \%13'ü 0-5 km, \%22'si 5$10 \mathrm{~km}, \% 9$ 'u 10-15 km, \%11'i 15-20 km, \%7'si 20-25 km, \%38'i ise $25 \mathrm{~km}$ üzerindeki mesafelerde bisiklet kullandıklarını belirtmiştir (Tablo 1).

Bisiklet kullanım amaçlarının yöneltildiği ve birden fazla seçime imkân tanındığı soruda ise katılımcılardan \%67'si sağlıklı yaşam ve spor için bisiklet kullanımını tercih ettiğini ifade etmiştir. Ayrıca, okul veya işe gidip gelmek ve genel ulaşım ihtiyacını karşılamak için kullananların oranı \%43 civarında çıkmaktadır. Katılımcıların yaklaşık \%30'u da bisiklet kullanımının çevresel etkilerinin önemine vurgu yapmışırır. 
Tablo 1. Bisiklet Kullanım Slklığı ve Sürüş Mesafesi

\begin{tabular}{|c|c|c|c|c|c|c|}
\hline & \multicolumn{3}{|c|}{ Cinsiyet } & \multicolumn{3}{|c|}{ Yaş } \\
\hline & Kadın & Erkek & 25 ve Alt1 & $26-40$ & $41-59$ & 60 ve Üzeri \\
\hline $\begin{array}{l}\text { Uygun hava koșullarında ne } \\
\text { stklikla bisiklet kullantrsinz?? }\end{array}$ & & & & & & \\
\hline Çok nadir bisiklet kullanırım & $\% 7$ & $\% 4$ & $\% 5$ & $\% 4$ & $\% 2$ & $\% 0$ \\
\hline Ayda birkaç gün & $\% 4$ & $\% 8$ & $\% 3$ & $\% 5$ & $\% 3$ & $\% 1$ \\
\hline Haftada 1-2 gün & $\% 8$ & $\% 17$ & $\% 5$ & $\% 13$ & $\% 6$ & $\% 2$ \\
\hline Haftada 3-4 gün & $\% 9$ & $\% 23$ & $\% 5$ & $\% 11$ & $\% 15$ & $\% 1$ \\
\hline Her gün & $\% 3$ & $\% 17$ & $\% 4$ & $\% 9$ & $\% 6$ & $\% 1$ \\
\hline $\begin{array}{c}\text { Bisiklet kullandlğıntz günlerde } \\
\text { ortalama yolculuk mesafeniz ne } \\
\text { kadardır? }\end{array}$ & & & & & & \\
\hline $0-5 \mathrm{~km}$ & $\% 9$ & $\% 4$ & $\% 5$ & $\% 6$ & $\% 3$ & $\% 0$ \\
\hline $5-10 \mathrm{~km}$ & $\% 10$ & $\% 12$ & $\% 6$ & $\% 11$ & $\% 4$ & $\% 1$ \\
\hline $10-15 \mathrm{~km}$ & $\% 2$ & $\% 7$ & $\% 3$ & $\% 3$ & $\% 2$ & $\% 0$ \\
\hline $15-20 \mathrm{~km}$ & $\% 3$ & $\% 8$ & $\% 1$ & $\% 7$ & $\% 3$ & $\% 1$ \\
\hline $20-25 \mathrm{~km}$ & $\% 2$ & $\% 5$ & $\% 1$ & $\% 4$ & $\% 2$ & $\% 0$ \\
\hline $25+\mathrm{km}$ & $\% 7$ & $\% 31$ & $\% 6$ & $\% 12$ & $\% 18$ & $\% 3$ \\
\hline
\end{tabular}

\subsection{Bisiklet Kullanım Potansiyeli:}

Katılımcıların bisiklet kullanım potansiyeline göre yapılan değerlendirmede likert tipi ölçek ile 7 maddede katılımları sorulmuştur. $\mathrm{Bu}$ maddeler ile katılımcıların hangi imkanlar dahilinde bisiklet kullanma potansiyellerinin artacağı ölçülmeye çalışılmıştır (Şekil 2).

Katılımcıların çok büyük kısmı, bisiklet altyapısının (yollar, park yerleri, bisiklet kiralama noktaları) etkin olduğu ve sürüş güvenliğinin sağlandığı durumlarda bisiklet kullanmayı düşündüklerini ifade etmiştir. $\mathrm{Bu}$ oran 1. madde hariç diğer maddelerde $\% 80$ üzerinde katılım göstermiştir. 1. maddede toplumda bisiklet kullananlara karşı olumsuz bir bakış açısının varlığı sorulmuş olup, katılımcıların cevapları herhangi bir yöne net bir eğilim göstermemektedir. Katılımcıların \%39'u olumsuz bir yargının varlığını düşünürken, \%47'si olumsuz bir yargı olmadığını belirtmiş, \%14'lük bir kesim de kararsız kalmıştır.

Sürüş güvenliğine atıf yapan 5. Maddede katılımcıların \%87'si sürüş güvenliği için gerekli önlemlerin alınması ile bisiklet kullanımını tercih edeceğini ifade etmiştir. Kesintisiz bisiklet yollarının planlanması (bütünlük-completeness) ise bir diğer yüksek katılım oranına (\%82) sahiptir.

Uygun altyap1 olması durumunda kentsel bölgelerde ya da kent dışı bölgelerde bisiklet kullanımı değerlendirmesinde, her iki durumda da yüksek katılım olmasına rağmen kentsel alanlardaki uzun parkurların daha çok tercih edileceği görülmektedir. Kentsel alanlardaki uzun parkurlar için katılım oranı \%82 iken kent dışı alanlarda bu oran \%73'te kalmıştır.

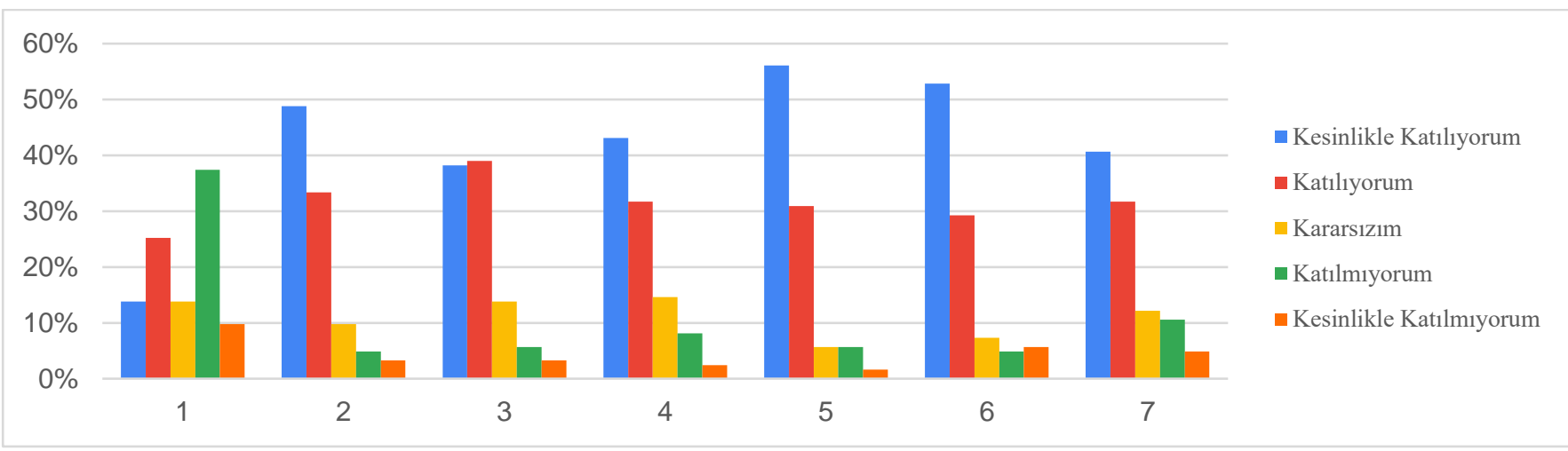

1. Toplumumuzda bisiklet kullananlara karşı olumsuz bir bakış açısı bulunmaktadır.

2. Kent içinde kesintisiz bisiklet yolları mevcut olsa bisiklet kullanırım.

3. Bisiklet kiralayabileceğim noktalar mevcut olsa bisiklet kullanırım.

4. Bisiklet park edebileceğim bisiklet park yerleri olsa bisiklet kullanırım.

5. Yollarda bisiklet sürücüleri için sürüş güvenliği açısından önlemler alınırsa bisiklet kullanırım.

6. Uygun altyapı olsa şehir içindeki uzun bisiklet parkurlarında (10km ve üzeri) bisiklet kullanabilirim.

7. Uygun altyapı olsa şehir merkezi dışındaki uzun bisiklet parkurlarında (10km ve üzeri) bisiklet kullanabilirim.

Şekil 2. Katılımcıların Bisiklet Kullanım Patansiyelinin Belirlenmesi 


\subsection{Uzun Bisiklet Parkurları Hakkında Değerlendirmeler}

Katılımcıların uzun bisiklet parkuları hakkındaki değerlendirmelerde ilk olarak algıları ölçülmeye çalışılmış ve bisiklet kullanıp kullanmama ve bisiklet kiralama tercihleri sorulmuştur. Sonuçlar incelendiğinde katılımcıların büyük bir kısmı uzun parkurlarda bisiklet kullanmayı isterken ancak yarısı uzun parkurlar için bisiklet kiralamayı tercih edebileceğini ifade etmiştir (Şekil 3).
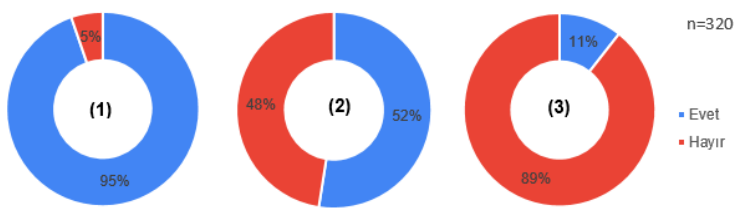

(1) Uzun bisiklet parkurlarında bisiklet kullanmayı düșünür müsünüz?

(2) Uzun bisiklet parkurları için $(10 \mathrm{~km}+)$ bisiklet kiralamayı düşünür müsünüz? (3) Samandağ-Arsuz arasındaki 26 km'lik bisiklet yolunda bisiklet kullandınız $\mathrm{m} 1$ ?

\section{Şekil 3. Bisiklet Kullanım Tercihleri}

Anket katılımcılarından bisiklet sahipliği ve kullanımına olumlu cevap verenler için her biri 7-8 maddeden oluşan 3 grup soru likert tipi ölçekte sunulmuştur. Bu maddeler ile aktif bisiklet kullanıcılarının uzun bisiklet parkurları ile ilgili düşünceleri ölçülmek istenmiştir. Bu ölçek maddeleri fiziksel altyapı, bisiklet yolu rekreasyon tesisleri, kurumsal etkiler, dijitalleşme ve parkur bilgileri kapsamlarında kendi içinde kategorize edilerek hazırlanmıştır.

İlk grup (A grubu maddeleri) likert tipi ölçekte kullanılan maddeler katılımcıların genel bakışını, parkur bilgilerinin erişilebilirliği ve kurumsal iletişimi ve sürüş esnasında kullanılan teknolojileri değerlendirmektedir (Şekil 4). Katılımcıların neredeyse tamamı (\%90) sürdürülebilirlik ve kentsel gelişim açısından uzun bisiklet parkurlarının tasarlanmasını önemli bulduklarını ifade etmiştir. Uzun bisiklet parkurlarını deneyimleme ve bu parkurlarda düzenlenecek turlara ve yarışlara katılma konularına anket katılımcıları olumlu yaklaşmaktadır ve yüksek oranlarda katılım isteği belirtmektedir. Katılımcılar uzun parkurlarda turlara katılmayı yarışlara katılmaya oranla daha fazla tercih etmektedir (sıras1 ile \%88 ve \%63). Bu değerlendirme grubu maddelerinde en düşük oranlar A5 ve A6 maddelerinde görülmüş olup bunlar mevcut parkur bilgilerinin erişilebilirliğini ve kurumların bu bilgileri paylaşımı konusunda etkinlik düzeyini ifade etmektedir. $\mathrm{Bu}$ durum, başta belediyeler olmak üzere dijitalleşme ve açık veri politikası konularında genel itibari ile kurumların yeterli olgunluğa ulaşmadığını göstermektedir (Creutzig vd., 2019).

İkinci grup (B grubu maddeleri) likert tipi ölçekte kullanılan maddeler uzun bisiklet parkurlarındaki rekreasyon alanlarının ve tesisleşmenin etkinliği hakkında hazırlanmıştır. Tüm sorularda ilgili maddelere katılım \%83 ile \%94 arasında değişmekte olup belirtilen maddelerin tamamının bu parkurlar için kritik öneme sahip olduğunu göstermektedir (Şekil 5). Anket katılımcıları uzun bisiklet parkurlarının toplu taşıma araçlarına ulaşımının rahat olmasını ve parkurlara yakın araç park yerlerinin olmasını ciddi derecede önemli bulmuştur. Ayrıca, bu parkurlara yakın konaklama hizmetinin; kamp, mesire ve dinlenme alanlarının; duş/tuvalet vb. hizmetlerin; alışveriş, kafeterya ve restoran imkanlarının gerekliliğini vurgulamışlardır.

Katılımcılara yöneltilen son grup ( $\mathrm{C}$ grubu maddeleri) likert tipi ölçekte fiziksel altyapı üzerinde durulmuştur (Şekil 6). Elde edilen değerlendirmede, yol yapım/yüzey kalitesini ve uygun yol işaretlemelerinin olmasını uzun parkurların kullanımı açısından \%97 üzerinde bir oran ile önemli bulunmuştur. Bisiklet ile ulaşımda katılımcıların \%99'u güvenlik konusunun önemli olduğunu vurgulamıştır. Anket katılımcılarının \%78'i bisiklet kullanmak için hava koşullarının iyi olmasını önemli olduğunu düşünmekte olup \%13'ü bu konuda kararsız kalmakta ve \%9'u hava koşullarının önemli olmadığını dile getirmektedir. Bisiklet parkurlarıyla ilgili yeterli bilgiye ulaşabilme konusunda ise bisiklet kullanıcılarının sadece \%64'ü katılım belirtmiş \%26 oranında ise kararsız kalmışlardır.

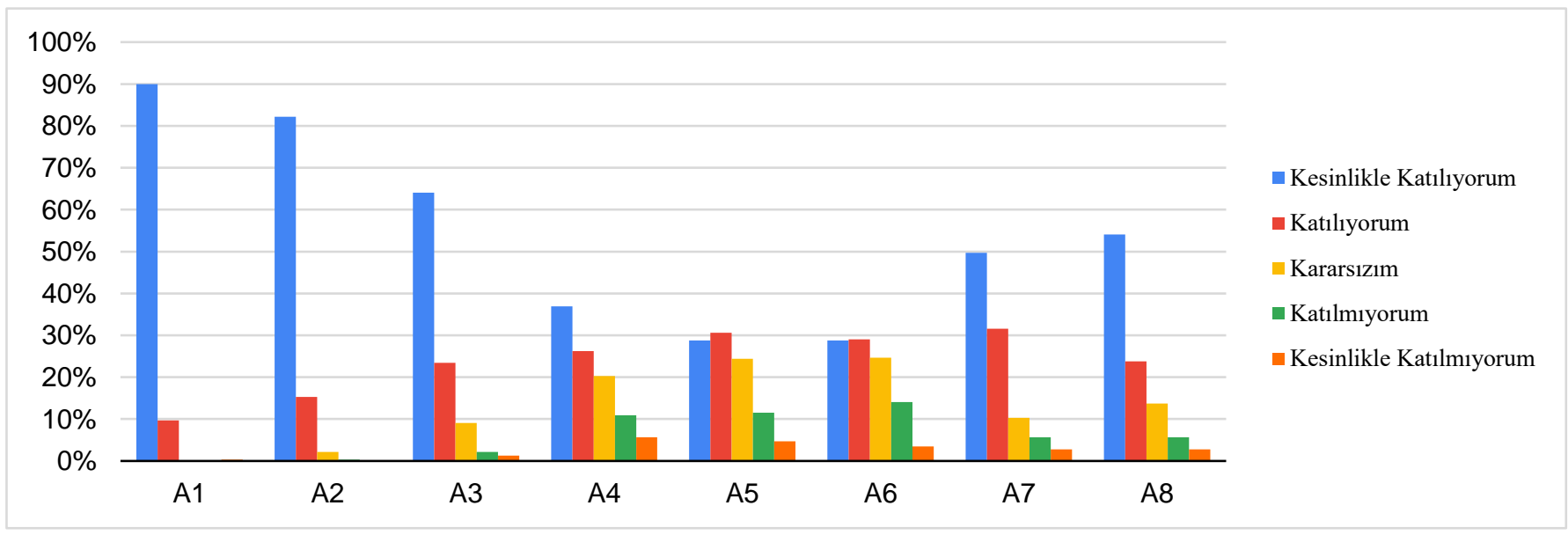

A1. Sürdürülebilirlik ve kentsel gelişim açısından şehirlerde uzun bisiklet yollarının tasarlanması önemlidir.

A2. Türkiye coğrafyasını göz önünde bulundurduğumuz zaman herhangi bir uzun bisiklet yolunu deneyimlemek isterim.

A3. Uzun bisiklet parkurlarında belirli aralıklarla turlar düzenlenirse bunlara katılmak isterim.

A4. Uzun bisiklet parkurlarında belirli aralıklarla yarışlar düzenlenirse bunlara katılmayı düşünürüm.

A5. Uzun bisiklet parkurlarının yerleri ve parkur özellikleri hakkında yeterli bilgi bulabilirim.

A6. İlgili kurumlar uzun bisiklet parkurlarıyla ilgili gerekli bilgileri web sayfası, mobil uygulama vb. üzerinden paylaşır.

A7. Sürüş yapacağım uzun bisiklet parkurlarını belirlerken online haritalardan faydalanırım.

A8. Sürüş yapacağım uzun bisiklet parkurlarında sürüş kayıt ve istatistikleri için mobil uygulamalardan faydalanırım.

Şekil 4. Uzun Bisiklet Parkurlarının Değerlendirmesi (A: Genel Katılım, Dijitalleşme ve Erişilebilirlik) 




B1. Uzun bisiklet parkurlarında toplu taşıma araçlarına erişiminin rahat olması önemlidir.

B2. Uzun bisiklet parkurlarının yakınında araç park yerlerin varlığı önemlidir.

B3. Uzun bisiklet parkurlarının yakınında konaklama hizmeti alabileceğim yerlerin varlığı önemlidir.

B4. Uzun bisiklet parkurlarının yakınında kamp yerlerinin varlığı önemlidir.

B5. Uzun bisiklet parkurlarının yakınında alıșveriș yapabileceğim yerlerin varlığı önemlidir.

B6. Uzun bisiklet parkurlarının yakınında mesire ve dinlenme alanlarının varlığı önemlidir.

B7. Uzun bisiklet parkurlarının yakınında duş/tuvalet vb. varlığı önemlidir.

B8. Uzun bisiklet parkurlarının yakınında kafe/restoran varlığı önemlidir.

Şekil 5 Uzun Bisiklet Parkurlarının Değerlendirmesi (B: Rekreasyon Alanları ve Imkanlar)

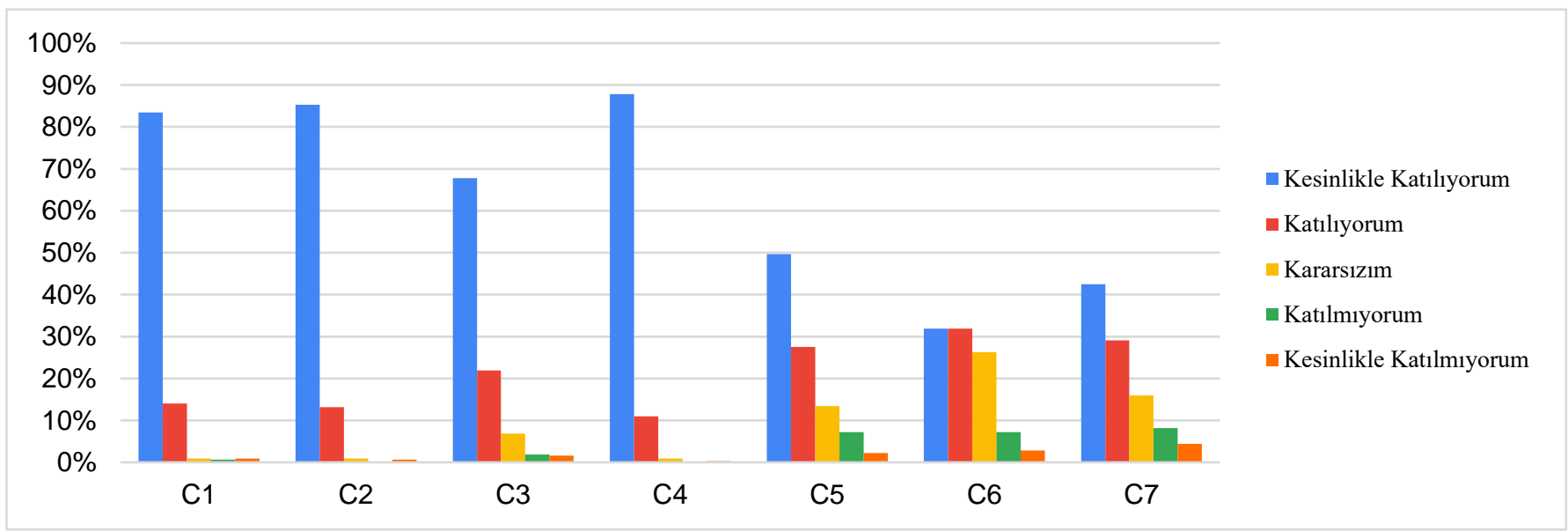

C1. Yol yapım/yüzey kalitesi bisiklet kullanımı açısından önemlidir.

C2. Uygun yol işaretlemelerinin olması parkurların kullanımı açısından önemlidir.

C3. Bisiklet park yerlerinin olması (bike rack) bisiklet kullanımı açısından önemlidir.

C4. Uzun bisiklet yolu ve çevresinin güvenli olması bisiklet kullanımı için önemlidir.

C5. Hava koşullarının iyi olması bisiklet kullanımı açısından önemlidir.

C6. Uzun bisiklet parkurları ile ilgili yeterli bilgiye ulaşabilirim.

C7. Uzun bisiklet parkurları yanında aracımı (otomobil vb.) park edebileceğim yerlerin olması önemlidir.

\section{Şekil 6 Uzun Bisiklet Parkurlarının Değerlendirmesi (C: Fiziksel Altyapı ve Güvenlik)}

\subsection{Uzun Bisiklet Parkurlarında Kullanıcı Görüşleri:}

Uzun parkur bisiklet kullanıcılarına son bölümde yöneltilen açık uçlu sorulara verilen cevaplar, kalitatif bir değerlendirmeye tabi tutulmuş ve içerik analizi yöntemi ile irdelenmiştir. Anket katılımcılarına yönlendirilen ilk açık uçlu soru "Uzun bisiklet yollarının kullanımında sizi en çok sınırlayan ve teşvik eden şeyler nelerdir?" olmuştur. Anket sonuçlarına göre bisiklet kullanıcılarını sınırlayan ve teşvik eden cevapların arasında en çok öne çıkan konulardan birinin 'güvenlik' olduğu gözlenmiştir. Son yıllarda artan bisiklet kullanımı ile paralel olarak artan bisiklet yollarında birçok can kaybı ve yaralanmalı kaza meydana gelmiştir.
Güvenli sürüşün tüm bisiklet kullanıcıları tarafından önemsendiği, kısıtlı güvenlik durumunun kullanıcıları kısıtlandırırken güvenlik önlemlerinin alınmış olmasının ise bisiklet kullanımını teşvik ettiği katılımcı yorumlarında güçlü bir şekilde vurgulanmıştır. Genel olarak verilen cevaplarda güvenlik sorunlarının bir kısmının insan davranışlarından bir kısmı ise bisiklet parkurlarının fiziksel altyapısından kaynaklandığı değerlendirilmiştir. Bisiklet yolları ile ilgili bu durumun motorlu araçların bisiklet yollarını kullanmaları, bisiklet yollarının üzerinde araçların park edilmesi, yayaların bisiklet yolları üzerinde yürümesi, araçlardaki sürücülerin bisikletlilere karşı dikkatsiz olmaları, yolların zemin kalitesinin bisiklet kullanımına uygun olmaması, yeterli 1şsklandırma ve yönlendirmenin olmaması başlıkları ile katılımcıların en çok dile getirdiği güvenlik sorunları olmuştur. 
Bisiklet kullanımını teşvik eden diğer konularından bazıları ise "motorlu araç kullanımında farkedilemeyen birçok doğal güzellik bisikletli ulaşımı tercih ettiğimiz zaman daha fazla hissedildiği" ve "daha kaliteli, temiz bir çevrede motivasyonel bir deneyim" olarak vurgulanmıştır.

Bisiklet kullanıcılarını en çok sınırlayan etkenlerin "bisiklet yolu kalitesinin düşük olması”, "yol bakımı ve zemin kalitesinin kötü olmasl" ve mevcut uzun bisiklet parkurları ya da bisiklet yollarının uzun bisiklet parkurları ile arasında bağlantı yollarının eksikliği temel altyapı problemleri olarak ortaya çıkmaktadır. Diğer yandan "temel ihtiyaçların karşllanabileceği yerlerin (kafeterya, restoran, WC, mesire alani, vb.) eksikliği”, ve olas aksilikler karşısında "tamir kiti ve benzeri önlemlerin" yeterli düzeyde olmaması özellikle uzun bisiklet parkurlarında kullanıcıları en çok kısıtlayan etkenler arasında bahsedilmiştir.

Anket katılımcılarına yönlendirilen ikinci açık uçlu soruda "Uzun bisiklet parkurlarının en güzel yanları ve sorunları nelerdir?" sorusu yöneltilmiş̦tir. Bisiklet kullanıcıları genel olarak bisikletli ulaşımın sağladığı sağlıklı bir yaşamı, fiziksel ve psikolojik olarak doğada var olabilmeyi ve birçok farklı deneyimi yaşayabilmeyi uzun parkurların en güzel yanları olarak dile getirmişlerdir. Ülkemizde motorlu araç ve yayaların bisikletli ulaşım konusunda bilinçsiz olmasını, bisiklet parkurlarının bakım ve onarımlarının düzenli olarak yapılmamasını ve bu parkurları kullanırken temel ihtiyaçlarımızı karşılayabileceğimiz alanların olmamasını ise uzun parkurlarda bisiklet kullanımının sorunları olarak dile getirmişlerdir.

Son olarak katılımc1lara "Uzun bisiklet parkurlarıla ilgili yetkili kurumlara önerileriniz neler olabilir?" sorusu yöneltilmiştir. $\mathrm{Bu}$ sorunun sorulmasındaki temel amaç, mevcut problemlere çözüm önerisi olabilecek bakış açılarının doğrudan bu altyapıyı kullanan ve eksikliklerden en çok etkilenen bireyler tarafından ortaya konulmasını sağlamaktır.

Altyap1 perspektifinden değerlendirildiğinde, en temel önerilerin planlama ve uygulama eksikliklerinin giderilmesi (bisiklet yolları arasındaki entegrasyon ve kopukluklar gibi), fiziki altyapı çalışmaları (bakım, onarım ve denetleme gibi) yol üstü tesislerin (dinlenme istasyonları, araç ve bisiklet park noktaları, WC ve kafeterya gibi tesisler, vb.) uygun yerlerde oluşturulması olarak ifade edilmiştir. $\mathrm{Bu}$ konuda yapılacak çalışmalar doğrudan ilgili kurumların yetki alanında olmakla birlikte, sosyal oluşumların, bisiklet kullanıcı gruplarının ve sosyal medya platformlarınında bu kurumlar üzerinde etkili olacağı aşıkardır. Ayrıca, sosyal medya ve geleneksel iletişism araçları ile "bisiklet parkurlarının tanıtımı ve reklam çalışmalarının gerekliliği " katılımcılar tarafından sıkça vurgulanmıştır. Mikro hareketlilik ve bisiklet kullanımını yaygınlaştırmaya çalışan bazı belediyelerin (Konya, Sakarya ve Eskişehir gibi) bu konuda proaktif yaklaşım sergilediği gerek altyapı ve kullanım gerekse reklam ve bilgilendirme çalışmalarını etkin bir şekilde yürüttüğü görülmektedir.

Katılımc1ların vurguladığı diğer bir konu ise "mevcut parkurların uzunluk, eğim, yol altyapısı, yol üstü tesisleri,” vb. bilgilerinin erişilebilir olmasının sağlanması hususundadır. Bu kapsamda gerek belediyeler veya ilgili kurumların gerekse veri paylaşımının açılması ile birlikte üçüncü parti geliştiricilerin bu bilgileri bisiklet kullanıcılarına sunması kolay erişilebilir bir hedef olarak gözükmektedir. Likert tipi ölçek ile yapılan değerlendirmede de ilgili kurumların dijitalleşme ve veri paylaşımı konusunda iyi bir performans ortaya koymadığı ortaya çıkmıştır (Şekil 4-Madde A6). Dijitalleşme ve bir sonraki aşama e-ISSN: 2148-2683 olan Akıllı Şehirler kavramları hem bilgi hem de verilerin erişilebilir ve işlenebilir olmasını elzem kılmaktadır.

\section{Sonuçlar ve Değerlendirme}

Yapılan çalışmada, bisiklet kullanımı ve özellikle uzun parkur bisiklet yolları hakkında kullanıcıların görüş ve değerlendirmeleri anket yöntemi ile incelemeye alınmıştır. Toplan 443 geçerli cevap alınan ankette, katılımcıların \%62'si erkek, \%38'i kadındır. En fazla katılımın \%42 ile 26-40 yaş aralığındaki gruplardan olduğu görülmüştür. Evli olmayanların (\%62), evli olanlara göre daha fazla bisiklet kullandığ 1 tespit edilmiştir.

Bisiklete sahip olmayan katılımcıların büyük çoğunluğunun bisiklet altyapısının yeterli olduğu güvenli parkurlarda bisiklet kullanma fikrine olumlu yaklaştığı görülmüştür. Anket katılımcıları birbirine entegre ve kesintisiz parkurlarda ve bisiklet park yerlerinin ve bisiklet kiralanabilecek yerlerin bulunduğu parkurlarda bisiklet kullanabileceklerini belirtmişlerdir. Kent içi ve kent dışı uzun bisiklet parkurları bisiklet kullanım potansiyelini olumlu yönde etkilemektedir. Toplumda genel olarak bisiklet kullanımına karşı olumsuz bir bakış açısı bulunmamaktadir.

Katılımcıların hava koşullarının uygun olduğu zamanlarda büyük çoğunlukla haftada 3-4 gün bisiklet kullandığ görülmüştür. İnsanların büyük çoğunluğunun (\%58) bisiklet kullanmak için asfalt/beton kaplamalı bisiklet yolunu (on-road) tercih ettikleri anlaşılmaktadır. İnsanların okula ve işe gidip gelmek, genel ulaşım ihtiyaçlarını karşılamak, sağlıklı yaşam ve spor yapmak ve çevresel etkileri azaltmak gibi amaçlarla bisiklet kullandıkları görülmektedir.

Uzun parkurları değerlendiren sorularda katılımcıların büyük çoğunluğu uzun parkurları deneyimlemek istediğini ifade etmiştir. Ancak, bu uzun parkurlarda bisiklet kiralama konusuna pek de sıcak bakılmadığı görülmektedir. Uzun bisiklet parkurlarının insanları teşvik eden olumlu yanları ve insanları sınırlayan olumsuz yanları hakkında yapılan değerlendirmelerde, bu parkurlarda bisiklet kullanan insanlar psikolojik ve fiziksel olarak doğa içinde olmanın keyifli bir deneyim oldugunu dile getirmişlerdir. Bisikletli ulaşımın sağladığı sağlıklı yaşam ve temiz havada bulunma düşüncesinin birçok insanın üzerinde olumlu etkiler bıraktığı görülmektedir.

Bisiklet parkurlarının bakım ve onarımların düzenli olarak yapılmaması ve bu parkurları kullanırken temel ihtiyaçlarımızı (mesire alanları, wc, duş, kafe, restaurant vb.) karşılayabileceğimiz alanların olmaması ise uzun parkurlarda bisiklet kullanımının en temel ve önemli sorunları olarak dile getirilmekte olup, bu problemin literatür ile de paralel sonuçlar içerdiği görülmektedir. Katılımcıların yol yapım kalitesinin düşük olmasından ve zemin kalitesinin yetersizliğinden genel olarak rahatsız oldukları belirlenmiştir.

Tüm bunlar göz önünde bulundurulduğu zaman, ülke genelinde uzun parkurlarda güvenli bir sürüş sağlanması açısından insanlar bisiklet kullanımı hakkında bilinçlendirilmelidir. Bisiklet parkurlarının planlama ve uygulama eksiklikleri giderilmelidir. Düzenli bakım ve onarım işlemleri yapılmalıdır. Bisiklet yollarının tanıtımlarına ve bisiklet kullanımının teşviğine ağırlık verilmelidir. Eğim, mesafe, yol kalitesi standartlara uygun şekillerde yapılmalıdır. Uzun parkurlarının yakınlarında araç ve bisiklet park yerleri tasarlanmalidir. 


\section{Kaynakça}

Altuntaş, T., Sertbaş, K., Gönener, U., Uzuner, M. E., Gönener, A. \& Bahadır, T. K. (2020). Yerel yönetimlerde fiziksel hareketin sürdürülebilirliğini destekleyen KOBİS (Kocaeli Bisikletli Ulaşım Sistemi) projesinin yönetim ve uygulama süreçlerinin incelenmesi. Sinop Üniversitesi Sosyal Bilimler Dergisi, 4 (1), 277-296. DOI: 10.30561/sinopusd.734593.

Barbieri, D. M., Lou, B., Passavanti, M., Hui, C., Hoff, I., Lessa, D. A., ... \& Rashidi, T. H. (2021). Impact of COVID-19 pandemic on mobility in ten countries and associated perceived risk for all transport modes. PloS one, 16(2), e0245886.

Barut, H. B. \& Yücetürk, G. (2017). Akdeniz Üniversitesi sosyal bilimler ve teknik bilimler öğrencilerinin bisikletli ulaşıma bakış açılarının değerlendirilmesi. Uluslararası Sürdürülebilir Mühendislik ve Teknoloji Dergisi, 1 (1), 25-30. Retrieved from

https://dergipark.org.tr/en/pub/usmtd/issue/32428/370431.

Barth, M., \& Boriboonsomsin, K. (2008). Real-world carbon dioxide impacts of traffic congestion. Transportation Research Record, 2058(1), 163-171.

Cengiz, T., \& Kahvecioğlu, C. (2016). Sürdürülebilir kent ulaşımında bisiklet kullanımının Çanakkale kent merkezi örneğinde incelenmesi. Tekirdağ Ziraat Fakültesi Dergisi, 13(2), 55-66.

Chen, C. F., \& Chen, P. C. (2013). Estimating recreational cyclists' preferences for bicycle routes-Evidence from Taiwan. Transport Policy, 26, 23-30.

Creutzig, F., Franzen, M., Moeckel, R., Heinrichs, D., Nagel, K., Nieland, S., \& Weisz, H. (2019). Leveraging digitalization for sustainability in urban transport. Global Sustainability, 2.

Litman, T., \& Burwell, D. (2006). Issues in sustainable transportation. International Journal of Global Environmental Issues, 6(4), 331-347.
Lumsdon, L. (2000). Transport and tourism: cycle tourism-a model for sustainable development?. Journal of Sustainable Tourism, 8(5), 361-377.

Özden, A., \& Şahin, S. N. A. (2020). Urban Mobility in Covid19: How We Adapted to Change and How Should We Respond. Academic Platform Journal of Natural Hazards and Disaster Management, 1(2), 96-109.

Öztürk, Ö. F., Çoruh, E. (2019). Gümüşhane İli İçin Bisiklet Ulaşımı Planlaması. Erzincan Üniversitesi Fen Bilimleri Enstitüsü Dergisi, 12 (3), 1283-1294. DOI: 10.18185/erzifbed.477598

Saplığlu, M., \& Aydın, M. M. (2018). Choosing safe and suitable bicycle routes to integrate cycling and public transport systems. Journal of Transport \& Health, 10, 236-252.

Schiller, P. L., \& Kenworthy, J. R. (2017). An introduction to sustainable transportation: Policy, planning and implementation. Routledge.

Vith, T. A., \& Mössner, S. (2017). Contesting sustainable transportation: bicycle mobility in Boston and beyond. DIE ERDE-Journal of the Geographical Society of Berlin, 148(4), 229-237.

Weston, R., Davies, N., Peeters, P. M., Eijgelaar, E., Lumsdon, L., McGrath, P., \& Piket, P. C. (2012). The European Cycle Route Network EuroVelo: challenges and opportunities for sustainable tourism.

Winters, M., Teschke, K., Grant, M., Setton, E. M., \& Brauer, M. (2010). How far out of the way will we travel? Built environment influences on route selection for bicycle and car travel. Transportation Research Record, 2190(1), 1-10.

Winters, M., Davidson, G., Kao, D., \& Teschke, K. (2011). Motivators and deterrents of bicycling: comparing influences on decisions to ride. Transportation, 38(1), 153-168.

Zhang, J., Hayashi, Y., \& Frank, L. D. (2021). COVID-19 and transport: Findings from a world-wide expert survey. Transport policy, 103, 68-85. 